\title{
Edward Albee's Who is Afraid of Virginia Woolf?
}

\author{
Yakup Yaşar \\ English Language and Literature Department, Ankara Üniversitesi
}

\section{Doi:10.5901/ajis.2013.v2n8p768}

\section{Abstract}

\begin{abstract}
In his play Edward Albee lays stress on the corruption in American society, American family in particular. Since World Wars I and II Americans have thought they are the winners of the wars; and so they are going to have such a comfortable and luxurious life in the future. However they have been influenced as deeply as 'the other' countries having lost the wars. The citizens of the loser sides have ended up in pathetic situations due to the massacres, genocides and forced emigration after the wars while the Americans have got damaged because of too much vanity and comfort making them ignorant. In addition, in his play Albee designates such kind of American family. There are couples George- Martha and Nick- Honey who have significant roles in the play. The former is an old couple having troubles in getting along with one another and treat behave in a corruptible manner whereas the latter is a younger couple seeming to love each other. Albee criticizes the corrupted American family institution by using irony and farcical dialogues. Each character stands for any American and they represent the degenerated relationships of them. Albee's use of words, character types and their farcical speeches create humor full of irony and satire. Even though the play is an example of an absurdist drama it has meaning in its meaninglessness.
\end{abstract}

Albee showed an interest in creative endeavors very early in life. His first attempts were with poetry, and by the time he was twelve, he had written his first play, a three-act farce called Aliqueen. He had his first poem published in a Texas literary magazine (Kaleidoscope) and also his first one-act play was published in the Choate Literary Magazine. While in Trinity College briefly, he became familiar with another side of the theater when he acted in a Maxwell Anderson play. In 1958, just before his thirtieth birthday, Albee finished The Zoo Story, the long one-act drama that would launch him on his career. After sending it to various theatrical producers in New York, a friend sent it to an acquaintance in Europe and it was finally produced in Berlin on September 28, 1959. After being a success there and being staged in numerous other cities in Germany, it was then presented in New York at the Off-Broadway Who's Afraid of Virginia Woolf?. Provincetown Playhouse in 1960. Albee attracted quite a bit of critical success with this play but not much popular success. Then in 1962, he achieved both critical and popular success with Who's Afraid of Virginia Woolf? The play won the coveted New York Drama Critics Award and every other major award except the Pulitzer Prize, and it was made into a very successful motion picture with slight, but sometimes important, changes from the dramatic script. Although Albee has continued to write significant drama (A Delicate Balance in 1966 won the Pulitzer Prize), none of his later plays have won the critical and popular acclaim awarded to Who'sAfraid of Virginia Woolf?(Roberts,4).

Even though this play is not directly related to The Theatre of The Absurd it includes a lot of characteristics of it. Indeed, Albee's other plays The Zoo Story, The American Dream, and Sand Box are much more related and called as absurdist plays. On the other hand what makes Who'sAfraid of Virginia Woolf? different from absurdist plays is its setting, its character types and its themes. However Albee uses the techniques of The Theatre of The Absurd such as corrupted language, fragmented dialogues, degenerated speeches, clichés and so on. What is more Albee lays stress on the goal of Existentialism in the play and he portrays his characters George and Martha as the ones struggling for their own self and existence by taking the other under his/her dominance. Additionally as Albee criticizes the corrupted American life in his play, it is obvious that the play has some relation with the Realist drama as well. Although it is not as serious as Henrik Ibsen's A Doll's House, it contains the real issues like Ibsen does in his play. Therefore, Albee can be called as a neo-absurdist playwright.

The setting of the play is a house of an American family located at New England college town of New Carthage. It stands for the Americans and their corrupted values. "Placing New Carthage in New England ironically links the setting of the play to one of its themes, "American values." New England was a birthplace of America's freedom and has long been considered a stronghold of solid American values." (Adams, 24). It is not as indefinite as in absurdist plays in general. The setting is nowhere in the world which resembles everywhere, whereas in Who is Afraid of Virginia Woolf? it is obvious and specific. The reason why Albee does so is because he is American and he is the member of the winner side of the wars, otherwise he would write as universally as Beckett, Jean Genet and Ionesco. 
They were responding differently to the world. World War II and the potential horrors of the nuclear age compelled these writers to see the universe as a place where humans had lost control. They were eager to shake audiences out of a sense of complacency about their lives. They wanted the spectator to feel their deep-seated anguish at the absurdity of the human condition. Nothing happens, nothing changes, these writers say. The world is out of control and nothing we can do will change this disturbing condition. (p. 9).

Viladimir and Estragon in Waiting for Godot and Old Man and Old Woman in Chairs are representatives of any one on the earth. Nevertheless in Albee's play as he "told Michael Rutenberg that George and Martha were deliberately named after George and Martha Washington and that the imaginary child could represent the uncompleted revolutionary spirit of this country." (Holtan, 46). He focuses on 'this country' and only the people living there.

What is more the term 'history' is mentioned very repeatedly in the play which means it has great significance for Americans as well. American history is full of dreams turning into nightmare at the end. As Holtan explains very clearly in his article "Who is Afraid of Virginia Woolf and the Patterns of History" that

One of the principal myths on which this country was founded was the notion that America was a New Eden, a second chance ordained by God or Providence in which man could begin all over again, freed from the accumulated sin and corruption of Western history. Not only could the American become a New Adam and found upon the unspoiled continent an ideal human polity, but this new way of life and new order of society could serve as a shining example to redeem erring Europe from her own sinfulness. America had established a covenant with God or with Nature (the myth had its beginnings with the Puritan settlements and became secularized as time went on) and could remain free of the vicissitudes of history provided she kept the terms of the covenant, retained her simplicity, shunned European complexity and sophistication and avoided the twin temptations of urbanization and industrialization. Unfortunately, such a dream of perfection could not find realization in an imperfect world; the troubles and complexities Americans thought they had left behind began to invade the New World. (p. 47)

It was 'American Dream' that caused the catastrophe to the Europe and 'the New World'. "As George fell short of Martha's expectations, so perhaps did Albee's America fall short of the expectations of Europe and of Providence." (p.49). Likewise, George's novel is also very important for readers to realize the degenerated condition of Americans. In his first novel George tells the story of a boy who kills his parents. The reason why George's father-in-law did not let him publish his book was because he thought he was the boy who committed that sin. For novel as a genre is generally based on the story of the society which the writer is a member of, George's novel designates that such bad incidents are common in America. George's making up a new novel at the time of game "Get the Guests" is about Nick and Honey's life. When they realize the story is the same as theirs Nick gets irritated and does not want him to go on, but Honey likes it. Still she does not understand it is definitely their own memory and says "I love familiar stories... they are the best" (II; 144). Later on she realizes that Nick has got married to her not because of their love but her money. Additionally, it is presented also Martha's father married his second wife for her money. George says "Martha's got money because Martha's father's second wife... not Martha's mother, but after Martha's mother died... was very old lady with warts who was very rich." (p. 109). Albee criticizes the marriages in America as well. He emphasizes the fact that the corruption has happened since money replaced love in family lives.

The games are important parts of the play too. In addition to the game mentioned above there are "Humiliate the Host", "Hump the Hostess", "Bringing up Baby". These games include both George and Martha's confessions about the past. They "are constantly playing games, matching wits, seeking the upper hand" ( Adams, 29). Their relationship is not normal. They do not treat each other consistently and their thoughts and feelings change continuously. Their "relationship seems grounded in masochism. Each invites the other to attack, so each can have an excuse for revenge. By describing what they do as 'games,' they create a socially acceptable ritual of abuse, an abuse in which they reveal to release their bitterness and self-loathing." (Abbotson, 141). What is more, the dialogues between George and Nick seem as if they were father and son talking to one another. George gives advice to him and Nick pretends to listen to him. After that when George's confessions begin to make him nervous he changes his attitude towards him oppositely. "The scenes between George and Nick have been compared to a chess match, with each player seeking the advantage over the other." ( $p$. 29). The most interesting game is "Bringing up Baby" in which it is realized the son mentioned throughout the play by George and Martha is not real. George breaks down the illusion by informing Martha their son is dead.

Death is one of the significant and fundamental elements in Albee's plays. He focuses on the point that "with death man faces the mystery of Being and Nothingness. Death brings man to the threshold of authentic existence; death is all over, universal as well as conclusive." (Vos, 85). Dying is not the act of vanishing into nothingness it is the journey to the actual existence. Albee questions this paradoxical situation in Who is Afraid of Virginia Woolf? as well. The death of the 
fictional son for instance presents that one can only be nothing if it is not existent at all; however no existent one can be no one by dying. In fact this problematic issue has been examined by existentialist as well. They have tried to come to the point that each person has their own existence individually and their individuality makes them peculiar; therefore everybody has inner discipline which makes it necessary to be responsible for any of their actions. This responsibility keeps the world in harmony and peace. What is more, it is merely acceptable for this life. When one dies it is not clear what it will encounter after death. The existentialists can not find any obvious and satisfying solution to this ambiguity, and they just support the assertion uttered by Nietzsche "God is dead". Albee lays stress on that and tries to question the idea of existence and death. He in a New York Times interview says "I had an awareness of death when I was 15, but I turned 36 or 37 before I became aware that I, Edward Albee, was going to die. The realization did not fill me with dread. I simply became aware of the fact that this is the only time around me". He points out death is as real as life itself, one who lives is going to die. The problem is not death it is the probability of losing existence. Being nothing is much more painful than being even in hell. Even though hell is the place of punishment and not as enjoyable as the place in Bernard Shaw's Man and Superman still it means one goes on its existence. Albee comes to the point "dying is a process which involves one's self is to gain self-knowledge" ( Vos, 85).

Moreover love is another important theme in the play. Albee makes a comparison between love and death in order to emphasize "the failure of love is a form of dying" (p.81). The corruption in George and Martha's love and the artificial love between Nick and Honey show what Albee aims at. He expresses the egoist characteristic of human beings. As the wife in his play All Over says "All we've done... is to think about ourselves. Ultimately." In Albee's plays people are good to only themselves. He criticizes the degenerated American society and the family institution in particular. In Who is Afraid of Virginia Woolf? For example George and Martha talk to each other as if they were two enemies put in a house and having no other choice but to try to get used to living together.

Martha: You didn't do anything; you never do anything; you never mix. You just sit around and talk. George: What do you want me to do? Do you want me to act like you? Do you want me to go around all night braying at everybody, the way you do? $(1 ; 7)$

Their attitude towards one another is not the ideal one between husband and wife loving each other, although they were in love in the past. Their marriage is not like Nick and Honey's marriage based on materialistic relationship. Nick has married honey for her father's properties, but George has not aimed at the same, otherwise he would not complain about Martha's father too much. However Nick and Honey's marriage seems more innocent. That is what Albee focuses on to express despite the fact that America was the winner of the both World War I and II, it has ended up in disappointment and corruption as well. Its catastrophe is not as tragic as the other countries beaten in the wars but much more problematic. The more individual people have become the lonelier they have been. Albee criticizes those people's pathetic condition very successfully in his plays. His characters "construct themselves a world of illusion which affords escape from their recurring sense of personal inadequacy. Illusion works for a time, but soon brings complications which wants redress. Albee therefore introduces illusion only to reassess it, to show his characters must rid themselves of falsehood and return to the world in which they must live." (Kingsley, 72). What is more George and Martha's artificial son is the production of their dream world, and Albee "purges illusion in the course of the play. This purgation is attained through Bringing Up Baby, during which George 'kills off' the fictive child." (p.72) and his death is the turning point for them to return to the real life.

The connection between illusion and real life is like the relationship between internal and external reality. George and Martha's playing games with Nick and Honey present they are restricted "between fantasy and real experience" (p.73). In their games they fictionalize stories to confess what they have experienced so far in order to inform the guests about their past. On the other hand they also make up a background for their 'fictive child', yet they try to impose their own story to Nick and Honey. This causes George and Martha to quarrel and they do not accept what the other say;

George: (...) She has a son who fought her every inch of the way, who didn't want to be turned into a weapon against his father, who didn't want to be used as a goddamn club whenever Martha didn't get things like she wanted them! Martha (Rising to it) : Lies lies!

George: Lies? All right. A son who would not disown his father, who came to him for advice, for information, for love that wasn't mixed withsickness- and you know what I mean, Martha- who could not toleratethe slashing, braying residue that called itself his MOTHER, MOTHER?

Martha: All right, you. A son who was so ashamed of his father he asked me once if it-possibly- wasn't true, as he had heard, from some cruel boys, maybe, that he was not our child; who could not tolerate the shabby failure his father had become... (III; 225) 
They behave as if all they tell were definitely true. They can not get along with each other even in their fantasies. "The major conflict typically involves characters reluctant to face the self in its pettiness and lack of fulfillment." (Kingsley, 79). That is to say George and Martha have problems not with one another but their own selves. Albee emphasizes individuality has brought out the loneliness in crowd which means no one understands and respects the other as they have lost their self awareness.

Furthermore, people have lost their ability to listen and speak. The unfinished sentences and interrupted speeches in Who is Afraid of Virginia Woolf? for instance demonstrate this pathetically absurdist situation quite obviously. Even though it is not as much as in Beckett's plays Albee's characters have the same fragmented dialogues too.

Nick: What I mean is... you two... you and your wife... seem to be having some sort of a...

George: Martha and I are having... nothing. Martha and I are merely...exercising... that's all... we're merely walking what's left of our wits. Don't pay any attention to it. (I; 33-4)

They pass to another topic very quickly while talking about something. "Much of the dialogue of the play consists of clichés, and Albee uses them in a manner that contributes to the truth/illusion situation". (Meyer, 63). They show the important unimportant and the unimportant important. "Each character is existing in his own private ego. Each makes a futile attempt to get another character to understand him, but as the attempt is contrived, there is more alienation." (Roberts, 11). It is one of the tragic results of the world wars, which put the countries in chaos.

The characters are indifferent to each other. Their ignorance is another result of the loss of their love. In fact it is the contribution of civilization which has appeared since the tragic world wars. The civilized people have looked down on the uncivilized. Not only have they scorned them but also killed them and haven't let them go on their life in peace. Civilization is claimed to be like "an enormous ocean", yet the sentence is incomplete. The whole should be civilization is an enormous ocean without water. George, Martha, Nick and Honey are the members of the civilized nation. They are the citizens of the country dominating the world but failing in dominating itself. As an absurdist playwright Beckett focuses on the pathetic and hopeless condition of postwar societies. He describes his characters as if they have no where to go and no hope to keep but just wait. Their act of waiting is the only action they do or they have to do. Vladimir and Estragon in Waiting for Godot for example are the representatives of all the victims of the civilized countries aiming at conquering the world. On the other hand the characters in Who is Afraid of Virginia Woolf? are the victims of civilization as well.

George (At Nick, not to him): you take the trouble to construct a civilization... to... to build a society, based on the principles of... of principle... you endeavor to make communicable sense out of natural order, morality out of the unnatural disorder of man's mind... you bring things to the saddest of all points... (II; 116).

They have not lost their hope like 'the others', yet they have lost their love, virtues and values. It is similarly disappointing and painful too. For example George seems indifferent to the adultery between his wife and Nick.

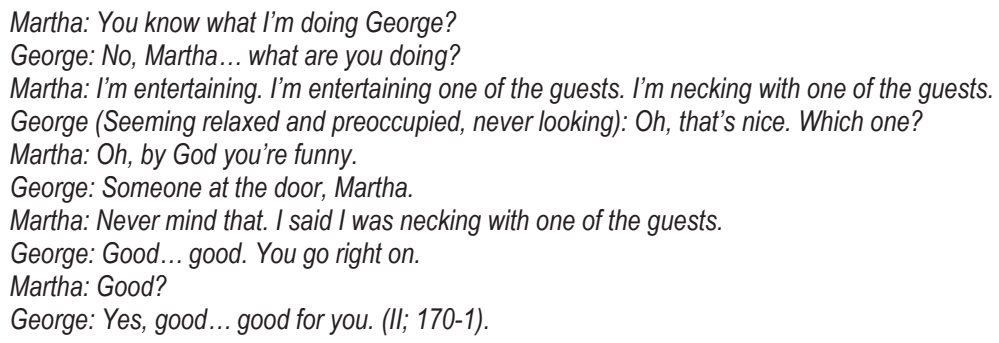

George's civilized attitudes towards Martha and the guests clearly demonstrate the corruption in American community. "We are exposed to several very civilized people acting in a way that is at times uncivilized and barbaric." (Roberts, 18). Albee emphasizes if the family gets corrupted then the society will get degenerated accordingly.

What is more, Nick and Honey are thought to be the next generation of George and Martha. Their marriage is also about to get corrupted, unless they take lessons from the old couple. Throughout the play George and Martha give examples from their own past and the young couple get influenced by them. Honey can not bear what she witnesses and she says "I'm going to... I'm going to be... sick..." (II; 148). On the other hand, Nick does not pay attention to his wife's illness and gets seduced by Martha very easily. 
Martha: (...) Now for being such a good boy, you can give me a kiss. C'mon.

Nick: Look... I don't think we should...

Martha: C'mon, baby... a friendly kiss.

Nick (Still uncertain): Well...

Martha: ... you won't get hurt, little boy...

Nick: ... not so little...

Martha: I'll bet you are not. C'mon...

Nick: But what if he should come back in, and ... or...?

Martha: George? Don't worry about him. Besides, who could object to a friendly little kiss? It's all in the faculty. We're a close-knit family here... Daddy always says so... Daddy wantsus to get to know each other... that's what he had the party for tonight. So c'mon... lets get to know each other a little bit.

Nick: It isn't that I don't want to... believe me...

Martha: You're a scientist, aren't you? C'mon... make an experiment... make a little experiment. Experiment on old Martha. (II; 163-4).

They commit adultery after getting too drunk. However they can not be successful at it due to Nick's impotence. Their "adultery is reduced to as farce."(Dozier). ${ }^{1}$ Both sex and drinking are also important themes of the play. The characters are drinking throughout the play and they see it as meaning of their life. As Honey says "I want my husband! I want a drink!" (II; 177) she implies both are equally important for her. The interrelation between her husband and a drink is questionable; whether her husband is as trifle as a drink or the latter is as necessary as the former is not clear enough. However it is fairly obvious, Albee ironically emphasizes that they live in a society "where civilization finally matters" (Adler, 68).

Taking everything into account, World Wars I and II have influenced all the countries no matter which have won or lost. The losers have had no where to go but wait for Godot, while the winners have had no aim to go but wait for going. Indeed metaphorically

Godot is an abbreviation of "Go, do it! Yes we have to go to do it, yet the problem is quite tragic; what is it? It is definitely what it is... I think it is the Death itself, but we do not have to wait for it every time as it comes suddenly without invitation an commands us "go, do it= die". Ultimately all the things will come to an end or a new beginning when the real game is over.

\section{References}

Abbotson, Susan C. W. Masterpieces of 20th Century America. London: Greenwood Press, 1961

Adams, Michael. Edward Albee's Who is Afraid of Virginia Woolf. New York: High School Principals Association of New York City, 1985

Adler, Thomas P. Who is Afraid of Virginia Woolf: A Long Night's Journey into Day. Educational Theatre Journal, Vol. 25, No. 1 (Mar., 1973), pp. 66-70

Dowd, Douglas. At the Cliff's Edge.(2007). USA: student edition

Dozier, Richard. "Adultery and Disappointment in Who is Afraid of Virginia Woolf?", Modern Drama, 11(Feb. 1969), pp. 432-436

Gray, Wallace. "The Uses of Incongruity". Educational Theatre Journal, Vol. 15, No. 4. (Dec., 1963), pp. 343-347.

Holtan, Orley I. "Who is Afraid Of Virginia Woolf? and The Patterns of History". Educational Theatre Journal, Vol. 25, No. 1(Mar., 1973), pp. 46-52. The Johns Hopkins University Press

Kingsley, Lawrence. "Continuity of a Theme in Albee". Educational Theatre Journal, Vol. 25, No. 1(Mar., 1973), pp. 71-79. The Johns Hopkins University Press

Meyer, Ruth. "Truth and Illusion in Who is Afraid of Virginia Woolf?". Educational Theatre Journal, Vol. 20, No. 1, $20^{\text {th }}$ - Century American Theatre Issue (Mar., 1968), pp. 60-69. The Johns Hopkins University Press

Roberts, James L. Edward Albee's Who is Afraid of Virginia Woolf. New York: Hungry Minds, Inc, 1979

Vos, Nelvin. "The Process of Dying in the Plays of Edward Albee". Educational Theatre Journal, Vol. 25, No. 1(Mar., 1973), pp. 80-85. The Johns Hopkins University Press

${ }^{1}$ Quoted in Thomas P. Adler's Who is Afraid of Virginia Woolf: A Long Night's Journey into Day. Educational Theatre Journal, Vol. 25, No. 1 (Mar., 1973), pp. 66-70 